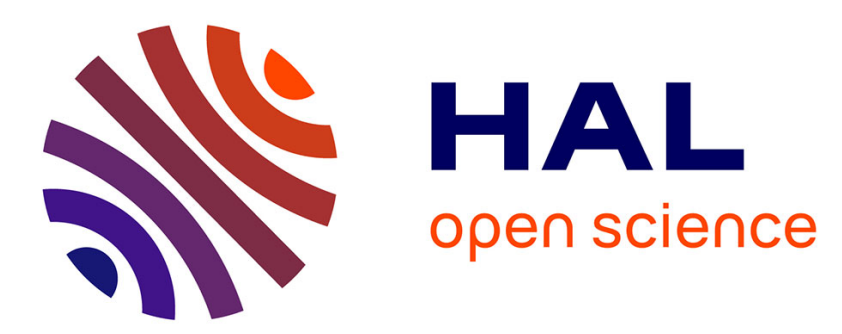

\title{
Nest site selection in the European wool-carder bee, Anthidium manicatum, with methods for an emerging model species
}

Ansel Payne, Dustin Schildroth, Philip Starks

\section{- To cite this version:}

Ansel Payne, Dustin Schildroth, Philip Starks. Nest site selection in the European wool-carder bee, Anthidium manicatum, with methods for an emerging model species. Apidologie, 2011, 42 (2), pp.181191. 10.1051/apido/2010050 . hal-01003585

\section{HAL Id: hal-01003585 \\ https://hal.science/hal-01003585}

Submitted on 1 Jan 2011

HAL is a multi-disciplinary open access archive for the deposit and dissemination of scientific research documents, whether they are published or not. The documents may come from teaching and research institutions in France or abroad, or from public or private research centers.
L'archive ouverte pluridisciplinaire HAL, est destinée au dépôt et à la diffusion de documents scientifiques de niveau recherche, publiés ou non, émanant des établissements d'enseignement et de recherche français ou étrangers, des laboratoires publics ou privés. 


\title{
Nest site selection in the European wool-carder bee, Anthidium manicatum, with methods for an emerging model species*
}

\author{
Ansel PAYNE ${ }^{1}$, Dustin A. SchILDROTH ${ }^{2}$, Philip T. STARKS ${ }^{3}$ \\ ${ }^{1}$ Division of Invertebrate Zoology, American Museum of Natural History, NY 10024 New York, USA \\ ${ }^{2}$ Department of Psychology, University of New England, ME 04005 Biddeford, USA \\ ${ }^{3}$ Department of Biology, Tufts University, MA 02155 Medford, USA
}

Received 6 February 2010 - Revised 11 May 2010 - Accepted 12 May 2010

\begin{abstract}
For many organisms, choosing an appropriate nest site is a critical component of reproductive fitness. Here we examine nest site selection in the solitary, resource defense polygynous bee, Anthidium manicatum. Using a wood-framed screen enclosure outfitted with food sources, nesting materials, and bamboo trap nests, we show that female bees prefer to initiate nests in sites located high above the ground. We also show that nest sites located at higher levels are less likely to contain spiderwebs, suggesting an adaptive explanation for nest site height preferences. We report size differences between this study's source populations in Boston, Massachusetts and Brooklyn, New York; male bees collected in Boston have smaller mean head widths than males collected in Brooklyn. Finally, we argue that methods for studying captive populations of $A$. manicatum hold great promise for research into sexual selection, alternative phenotypes, recognition systems, and the evolution of nesting behavior.
\end{abstract}

\section{Megachilidae / introduced species / solitary bee / enclosure methods}

\section{INTRODUCTION}

The European wool-carder bee, Anthidium manicatum (Hymenoptera: Megachilidae), is a Palearctic solitary bee species best known for its hyper-aggressive males and resource defense polygynous mating system (Ward, 1928; Pechuman, 1967; Severinghaus et al., 1981; Starks and Reeve, 1999). Males obtain and defend floral territories that females visit for food resources and nesting materials (Kurtak, 1973; Severinghaus et al., 1981; Müller, 1987); in the process, they routinely attack both conspecific males and heterospecific pollinators, sometimes lethally injuring the latter (Ward, 1928; Severingaus et al., 1981; Wirtz et al., 1988). A. manicatum also exhibits a male-

Corresponding author: A. Payne,

ansel@post.harvard.edu

* Manuscript editor: Klaus Hartfelder biased sexual size dimorphism unusual among bees (Darwin, 1871; Severinghaus et al., 1981; Shreeves and Field, 2008). Previous research has shown that male size correlates with mating success (Müller, 1987; Starks and Reeve, 1999), and that small males routinely adopt alternative mating tactics if unable to wrest control of territories from larger rivals (Starks and Reeve, 1999). All of these reasons, along with the bee's status as an introduced species in North America, South America, and New Zealand (Gibbs and Sheffield, 2009), make $A$. manicatum a promising system for the study of sexual selection, alternative phenotypes, and invasion ecology.

Less appreciated is the species' potential as a model organism in studies of aculeate nesting behavior and of the recognition systems that make it possible. A. manicatum is a member of the Anthidiini, a tribe of 
megachilid bees that engage in elaborate and highly derived nesting behaviors (Melander, 1902; Michener, 2000). Some of these genera, e.g. Dianthidium, construct exposed nest cells made of tiny pebbles embedded in conifer resin, while others, such as Hoplostelis, are obligate cleptoparasites of other bee species. Still other genera, including Anthidium, build their nests in pre-existing cavities that they line with the harvested trichomes of wooly plants (Michener, 2000).

A. manicatum is perhaps the best studied of these "wool-carder" bees. Several European authors have contributed notes on the species' nesting biology (Westrich, 1989 and references therein; K. Hartfelder, unpubl. data), and brief descriptions of the nests themselves date back to at least the 19th century, when Darwin's correspondent Frederick Smith (1855) outlined their basic structure. Shortly after, Kirby and Spence (1857) reported seeing females at least twice build their nests inside "the lock of a garden-gate". but suggested that nests were more likely to be found in cavities in old trees. In spite of this long history, however, detailed descriptions of female nesting behavior did not emerge until Kurtak explored the topic in an unpublished 1973 masters thesis. In it, she described a small number of nests recovered from traps placed in the greater Ithaca, New York, region shortly after the bee's putative introduction to North America. Utilizing a small screen enclosure, she also reported the first known observations of females in the act of nest construction.

Using their sharply toothed mandibles, female wool-carder bees strip the trichomes, or pubescence, from the leaves and stems of various plants, roll this pubescence into a ball, and carry it to some pre-existing cavity. Once inside, the bees shape the pubescence into cells where they deposit an egg and a provisioning mass made of nectar and pollen. A female constructs at least one, but usually several, cells within a single cavity, then seals up the entrance with various bits of organic and inorganic material that it carries to the nest; taken together, this material forms the nest's "terminal plug". New bees either emerge later that summer as the second generation of a bivoltine life cycle, or overwinter as prepupae and emerge the following spring (Kurtak, 1973).

Ulitmately, Kurtak (1973) based her observations on only a limited number of incomplete nests $(N=2)$ built inside her screen enclosure. To date, few nests have been recovered in nature (Pechuman, 1967; Kurtak, 1973; Severinghaus et al., 1981) and, despite Sugiura's (1994) success trap nesting captive A. septemspinosum, a similar effort using $A$. manicatum was largely unsuccessful (Kurtak, 1973). To our knowledge, there have been no previous experimental studies of either nesting behavior or nest site selection in this species.

Here we describe an experimental study of nest site selection undertaken with a captive population of A. manicatum during the summer of 2009. We present findings on size differences between two populations within the northeastern United States, and we test the hypothesis, based on suggestive findings by Severinghaus and colleagues (1981), that females prefer to initiate nests in locations high above the ground. We also present a possible adaptive explanation for this behavior. Finally, we argue that this study's methods allow for much greater experimental control than can be achieved through traditional field methods. We suggest that our methods therefore hold great promise for future studies of sexual selection, alternative phenotypes, recognition systems, the evolution of nesting behavior, and many other topics in evolutionary biology.

\section{MATERIALS AND METHODS}

\subsection{Collection methods}

Between 26 June and 11 August 2009, we captured live Anthidium manicatum from two urban field sites near Boston, Massachusetts, USA (Tufts University campus: $42^{\circ} 24.4^{\prime} \mathrm{N}, 71^{\circ} 07.1^{\prime} \mathrm{W}, N=$ 11; Longfellow National Historic Site: $42^{\circ} 22.63^{\prime} \mathrm{N}$, $\left.71^{\circ} 07.56^{\prime} \mathrm{W}, N=11\right)$ and from one in Brooklyn, New York, USA (Brooklyn Botanic Garden: $40^{\circ} 40.1^{\prime} \mathrm{N}, 73^{\circ} 57.8^{\prime} \mathrm{W}, N=35$ ). Each of these sites contained cultivated flower beds of perennial plants visited by A. manicatum (at Tufts: Nepeta sp. L. (Lamiaceae); at Longfellow National Historic Site: Salvia $\times$ suberba (Lamiaceae), Antirrhinum majus 
L. (Scrophulariaceae), Digitalis purpurea L. (Scrophulariaceae), Artemisia sp. L. (Asteraceae); at Brooklyn Botanic Garden: Teucrium chamaedrys L. (Lamiaceae), Calamintha nepeta (L.) Savi (Lamiaceae), Lamium maculatum L. (Lamiaceae), Salvia sclerea L. (Lamiaceae), Antirrhinum majus L., Nepeta sp. L.). All collections were made between 9:30 and 15:30 hr using aerial insect nets.

Using individual glass vials, we transported captured bees to the International Social Insect Research Facility (I.S.I.R.F.) at Tufts University, where we chilled them on ice for 3 minutes, temporarily immobilizing them. While the bees were inactive, we measured the widths of their heads to the nearest $0.05 \mathrm{~mm}$ using Dialmax SPi2000 dial calipers, repeating each measurement 3 times per individual and averaging the values as in Müller (1987). We then marked the dorsal sides of the bees' thoraces with individual-specific color combinations of Testors enamel paint. After marking, we allowed the bees to recover within the wood-framed screen enclosure described below.

In addition to these 57 bees, we collected $14 \mathrm{~A}$. manicatum at the Brooklyn site on 19 August 2009. We killed these bees on-site by submersion in $100 \%$ ethanol, then transported them to I.S.I.R.F. to obtain head width measurements using the protocol described above. These bees, as well as dead individuals recovered from the enclosure throughout the season $(N=37)$ and those bees remaining alive at the end of the study on 24 August $2009(N=2)$, were placed in individual tubes in $100 \%$ ethanol and stored at $-20^{\circ} \mathrm{C}$. Several bees $(N=18)$ were not recovered from inside the enclosure, and their bodies were presumed lost inside crevices in the floor or in cracks in the wooden walls; given the precautionary double doors (see below) and periodic checks on the integrity of the screen, it is unlikely that any of these bees escaped.

\subsection{Animal husbandry and the field enclosure}

To simulate natural conditions, we outfitted a previously existing, wood-framed screen enclosure ( $4.8 \mathrm{~m}$ long $\times 2.7 \mathrm{~m}$ wide $\times 2.0 \mathrm{~m}$ tall $)$ with large pots containing plants used by A. manicatum for nectar and pollen (Salvia sp. L., Nepeta sp. L.) and for nesting materials (Stachys byzantina Koch (Lamiaceae)) (Fig. 1). If a plant appeared unhealthy, we moved it outside the enclosure for a short time to maximize its exposure to full sunlight; thus, the

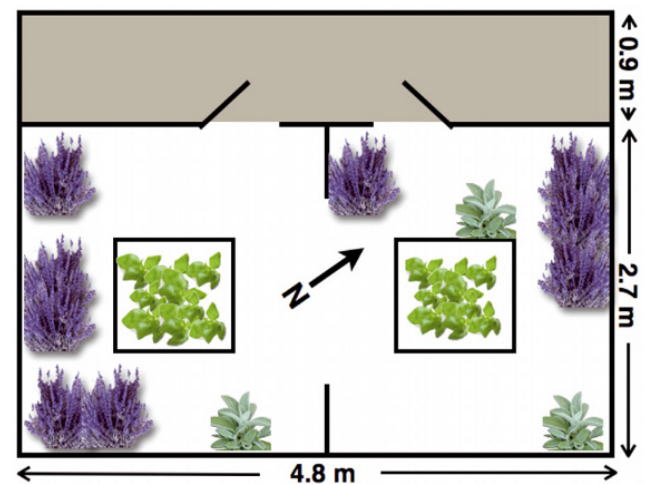

Figure 1. Stylized diagram of the I.S.I.R.F. Anthidium enclosure, a wood-framed screen structure open to sunlight through the northwest and southeast walls and through the plexiglass roof. The enclosure contained two small herb plots planted with Rosmarinus officinalis L., Origanum vulgare L., and Ocimum basilicum L., and pots containing Salvia sp. L., Nepeta sp. L., and Stachys byzantina Koch. We attached bamboo trap nests $(N=295)$ to each wall of the enclosure in bundles of between 4 and 8 .

total number of pots within the enclosure varied throughout the season ( $N=$ between 3 and 12 for each species). We also planted Rosmarinus officinalis L. (Lamiaceae), Origanum vulgare L. (Lamiaceae), and Ocimum basilicum L. (Lamiaceae) (itself a source of nectar and pollen), in two small herb plots located within the enclosure. Double doors at the front of the structure prevented bees from escaping, while a plexiglass roof and screened openings on the northwest and southeast walls allowed for direct sunlight for at least six hours on sunny days. In addition, we provided bees with shallow dishes of water ad libitum. To prevent the loss of nests to foraging ants, on 16 July we distributed TAT ${ }^{\circledR}$ Ant Traps $(N=6)$ and Terro ${ }^{\circledR}$ Ant Killer Liquid Baits $(N=6)$ throughout the enclosure and at various heights along the walls.

\subsection{Trap nesting}

On each wall of the enclosure, we mounted horizontal trap nests $(N=295)$ constructed from lengths of dried bamboo (55-245 mm; mean $=145.30 \mathrm{~mm} \pm 41.76)$ opened at one end and closed at the other by a node. The entrance diameters ranged from $4.2-19.2 \mathrm{~mm}$ (mean $=13.27 \mathrm{~mm} \pm$ 2.10). We bundled these trap nests with bailing 


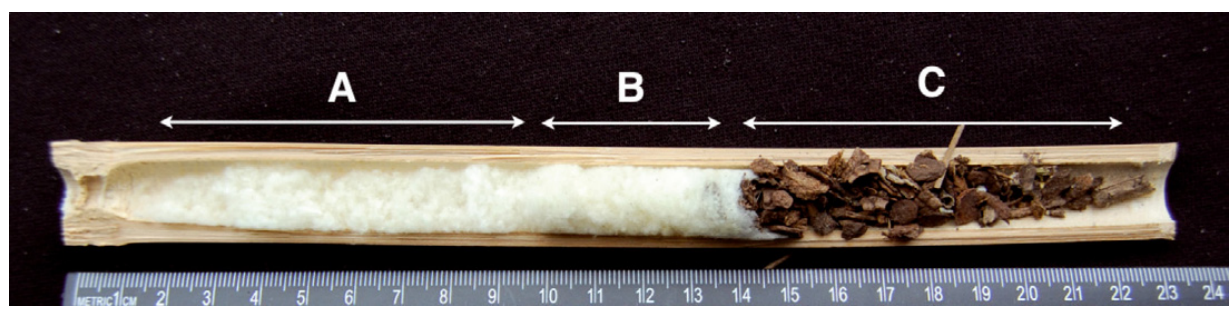

Figure 2. A completed nest opened by the authors on 9 October 2009. This nest contained loose flocculence at the distal end of the tube (A), followed by a single cell (B), and a terminal plug composed of detritus from the herb plots (C). Stachys byzantina Koch plants located inside the enclosure provided the source of pubescence. The reference scale is in centimeters.

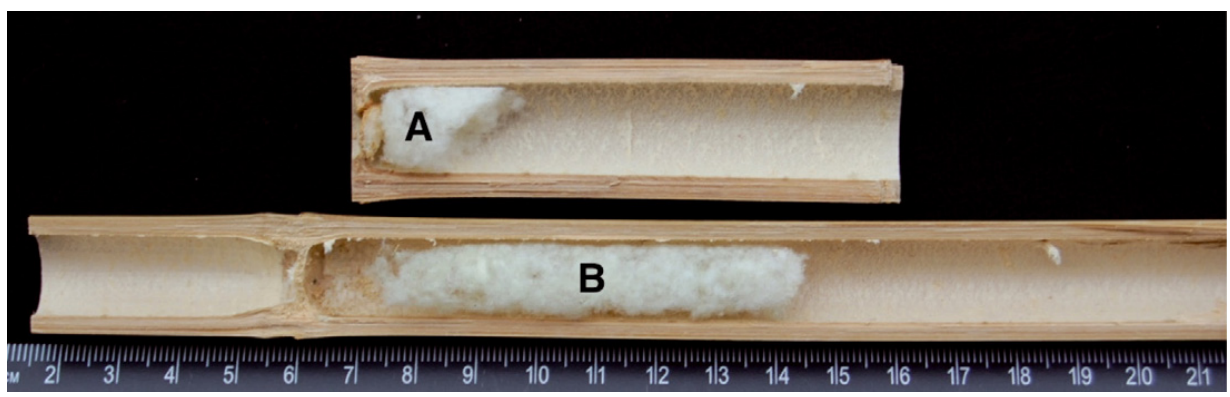

Figure 3. Two incomplete nests opened by the authors on 10 October 2009. The top nest contained an unused and incomplete cell (A), while the second nest contained loose flocculence without cells (B). These structures were typical of those nests that lacked completed cells. The reference scale is in centimeters.

twine into groups of between 4 and 8 with entrances pointing in both directions parallel to the walls. We then placed the traps at one of three height levels within the enclosure (low: $<35 \mathrm{~cm}$ above ground, $N=70$; middle: $80-95 \mathrm{~cm}, N=98$; high: $>165 \mathrm{~cm}$, $N=127$ ) and, due to the original placement of the structure, oriented each trap nest's entrance toward one of four intermediate cardinal directions (northeast, $N=70$; southwest, $N=82$; southeast, $N=71$; northwest, $N=72$ ).

We also mounted a small number of vertical trap nests $(N=17)$ at a height of approximately $140 \mathrm{~cm}$ along the southeastern wall of the enclosure; approximately half $(N=9)$ of these traps were arranged with their entrances pointing downward, while the others opened upward. These trap nests were ignored by bees and thus are not included in subsequent analyses of height or orientation preferences or of spiderweb presence.

In mid-October, we opened a small number of trap nests containing wool $(N=9)$ and photographed the contents. Three of these nests are depicted in Figures 2 and 3. We left the remainder of the nests inside the enclosure to await spring eclosion.

\subsection{Data collection and analysis}

Between 23 July and 23 August 2009, we surveyed each trap nest twice weekly with a small flashlight to record the presence or absence of plant pubescence. As this pubescence (hereafter "wool") could only have been transported to the traps by $A$. manicatum females, we used its presence as a proxy for nest initiation. The wool was easy to spot, as its distinctive glistening appearance set it apart from the light background of the trap nest interior. During the late August surveys, we also recorded any nests that contained a quantity of organic or inorganic matter indicative of a terminal nest plug. The presence of a plug implied that the female had finished her nest, and we scored these nests as "completed".

During this period, we also monitored trap nests for the presence of spiderwebs built on or inside the trap nest entrances. Once detected, spiderwebs were removed and their presence recorded. In the final analysis, we scored each trap nest according to (a) whether or not it had ever contained wool; (b) whether or not it was completed with a terminal plug; and (c) whether or not it had ever contained a 


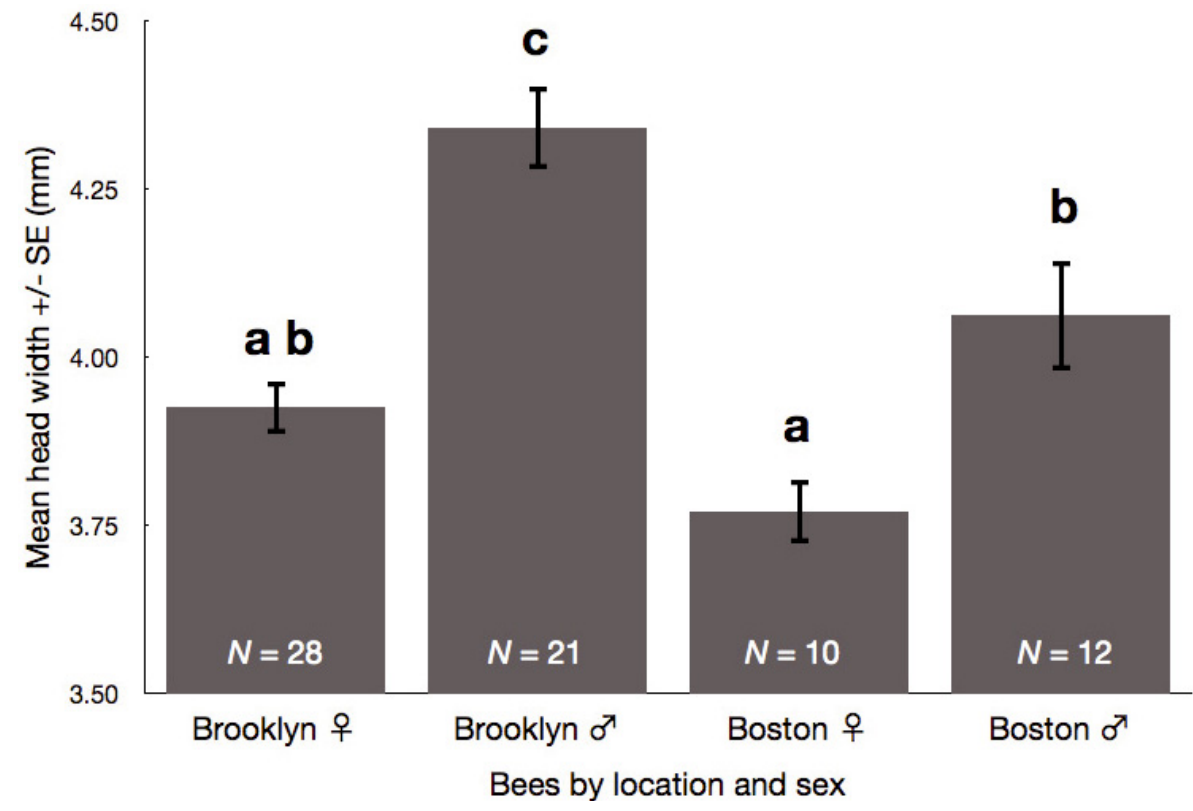

Figure 4. Mean head widths (+/- $1 \mathrm{SE}$ ), arranged by location and sex. Males from the Brooklyn population were on average $6.9 \%$ larger than their Boston counterparts. In the Brooklyn population, males were $10.7 \%$ larger than females; in Boston, males were 7.7\% larger. Letters represent significant differences.

spiderweb. These scores were applied regardless of the trap nest's status on the last day of the surveys.

Before analyzing head width data, we first established the normality of each distribution using a Shapiro-Wilk test (for each sex by location, $W>$ $0.92, P>0.35)$ and the homogeneity of variances using Levene's test ( $W=2.692, P>0.05)$. Differences in mean head width among sex/locations categories were analyzed using a one-way ANOVA, followed by a post-hoc Tukey-Kramer test in SPSS GradPack $^{\circledR}$ software (SPSS, 2008). Nest site preferences and spiderweb data were analyzed using chi-square tests; for small sample sizes, we used Fisher's exact test carried out in StatXact $6{ }^{\circledR}$ software (Cytel, 2003).

\section{RESULTS}

\subsection{Head width as a function of sex and location}

Males were significantly larger than their female counterparts in both the Boston $(P<$ $0.05)$ and Brooklyn populations $(P<0.001)$ (Fig. 4). There was also a significant size difference between Brooklyn males and Boston males $(P<0.05)$, but Brooklyn females were not significantly larger than Boston females $(P>0.20)$. There was no significant size difference between Boston males and Brooklyn females $(P>0.20)$.

\subsection{Survival rate and behavior within the enclosure}

Mortality within the enclosure was high, $35(61.4 \%)$ of the introduced bees were not seen alive again after the day of introduction (Fig. 5). Of these, 23 were among the cohort of 35 bees transported from Brooklyn to the Tufts University campus on 5 August 2009. Nevertheless, bees that survived the first day quickly adapted to life within the enclosures, and among this group the average life spans of females (23.0 days \pm 8.67) and males (13.6 days \pm 13.31 ) were long enough to exhibit the full range of behaviors recorded under natural conditions. These behaviors included feeding, territorial patrols by large males, aggression between males, successful and unsuccessful copulation attempts, collection of 


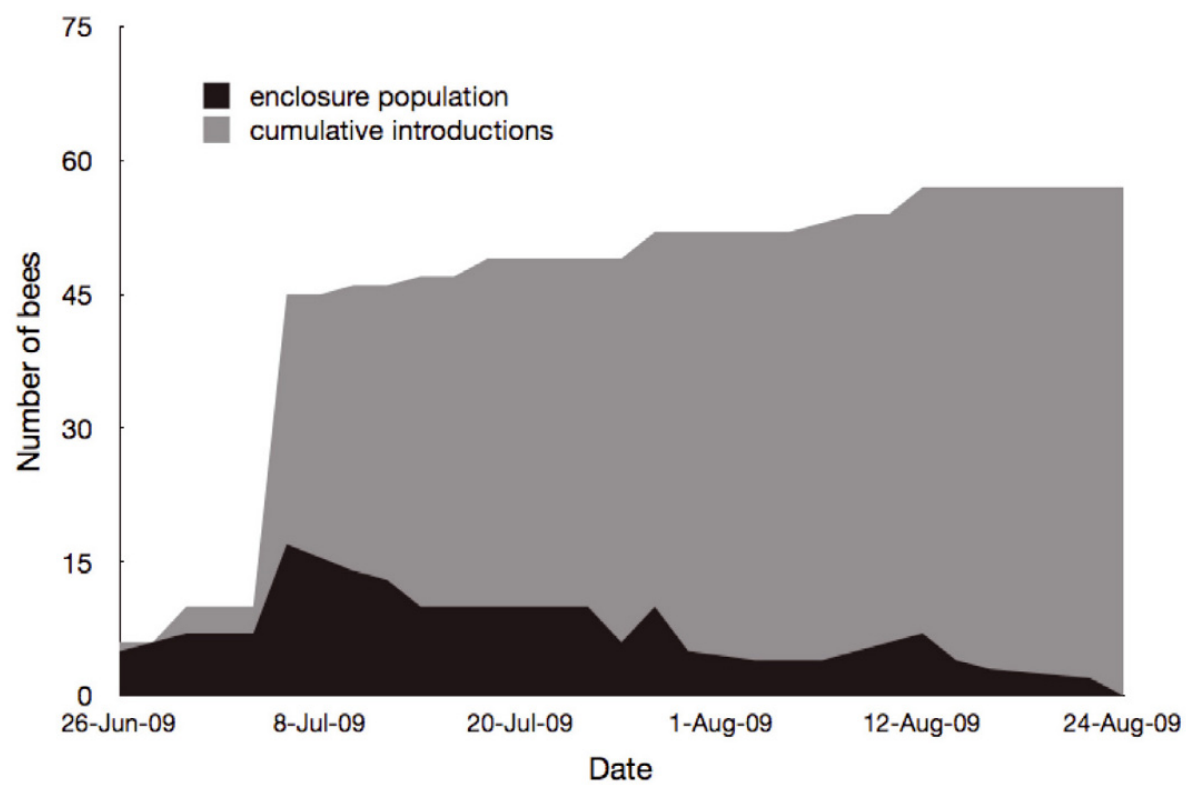

Figure 5. Cumulative introductions of bees and surviving bee populations by date. We surveyed bees at irregular intervals throughout the field season to record which individuals were present inside the enclosure.

pubescence by females, and nest construction (Kurtak, 1973). As the enclosure was closed to heterospecifics, we did not observe the interspecies aggression described by several authors (Ward, 1928; Severingaus et al., 1980; Wirtz et al., 1988).

\subsection{Trap nesting results}

On days when the bees were active, we observed individual females delivering wool to, and presumably provisioning, multiple nests concurrently. At the end of the field season, 50 of the enclosure's 295 trap nests contained wool, and 5 of these contained terminal plugs indicative of completed nests. The bees used trap nests with diameters ranging from 9.5-15.6 mm, and lengths ranging from 79-222 mm. Trap nest orientation had no significant effect on female nest site selection (northeast $=17$, southwest $=16$, southeast $=$ 9 , northwest $=8 ; \chi_{\mathrm{df} 3}^{2}=4.773, P=0.189$ ), although there was a slight trend in favor of trap nests oriented toward the northeast and southwest. Height, meanwhile, had an extremely significant effect on nest site selection: females overwhelmingly chose to initiate nests in traps positioned at the highest level within the enclosure $\left(\chi_{\mathrm{df} 2}^{2}=34.89, P<0.0001\right)$, though there was no significant difference between traps located at the low and middle levels (Fisher's exact test, $\chi_{\text {df } 1}^{2}=2.806, P=$ 0.15) (Fig. 6). Females also completed significantly more nests in the high traps than in either middle or low traps (Fisher's exact test, $\left.\chi_{\text {df } 2}^{2}=6.601, P=0.0317\right)$ (Fig. 7).

We found no evidence of wool in any of the vertical trap nests, though the sample size was too small to achieve statistical significance. In fact, with the exception of a single male that climbed into a downward facing trap nest during a storm, we never saw bees enter vertical traps.

By the end of the field season, 62 of the 295 horizontal trap nests had contained at least one spiderweb either on or within their entrances; two of these traps, one at the high level and another at the middle level, also contained wool. Height had a significant effect on spiderweb construction, though the pattern was 


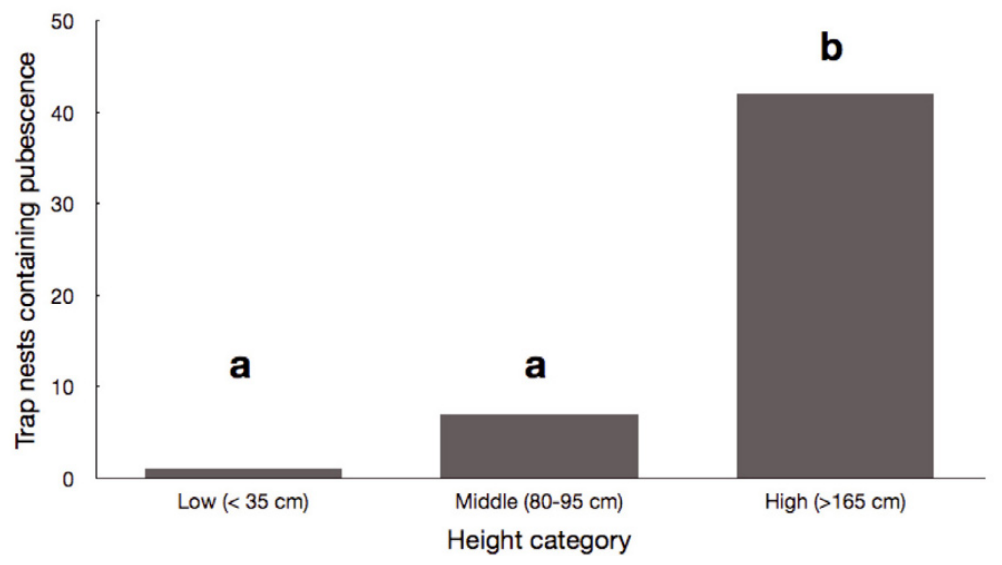

Figure 6. Number of pubescence containing trap nests arranged by height level. Bees showed a significant preference for transporting pubescence to high trap nests over low and middle traps; there was no significant difference between the number of pubescence containing trap nests at the low and middle levels.

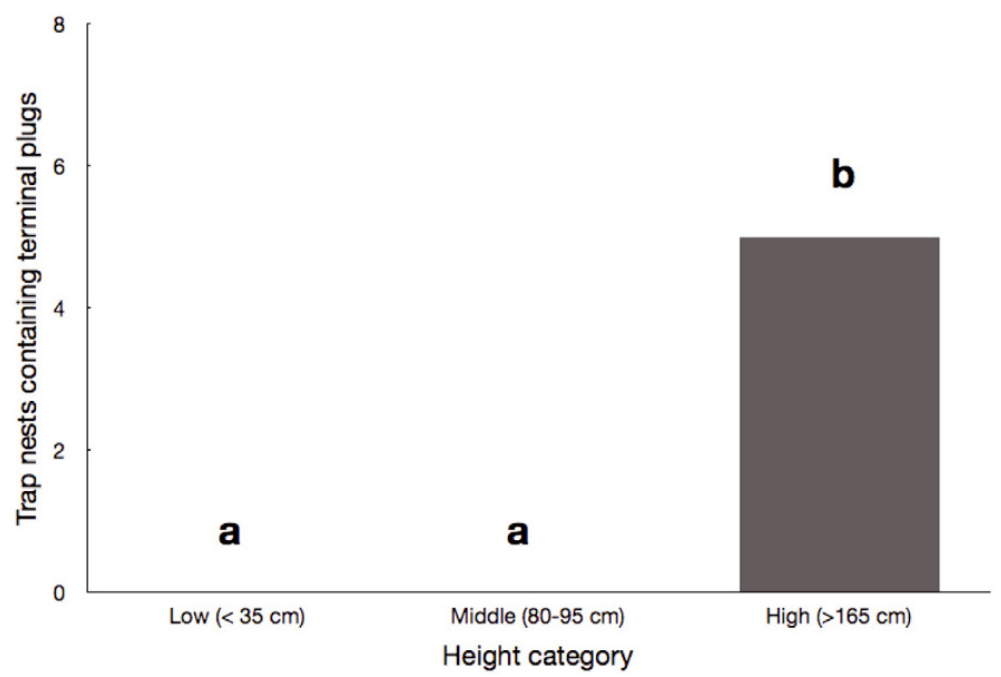

Figure 7. Number of trap nests containing a terminal plug (i.e., "completed" trap nests) arranged by height level. Bees showed a significant preference for initiating terminal plug construction in high trap nests; we found no evidence of terminal plugs at either the low or middle levels.

the reverse of that seen in wool deposition $\left(\chi_{\text {df } 2}^{2}=20.26, P \ll 0.0001\right)$ (Fig. 8).

\subsection{Ant presence within nests}

On 15 July, we observed a number of large bodied ants (Formica sp.) inside a high level, wool containing trap nest. The ants were concentrated in the area immediately in front of the wool, and several of them appeared to be feeding on this material. Bits of loose flocculence hung from the edge of the nest entrance, and there was a small amount of terminal plug-like debris (bits of sawdust, wood splinters, and at least one very small $[<2 \mathrm{~mm}]$ snail shell) located in the trap nest's proximal end. When we returned to the nest the next day, the ants were still inside, but the wool was almost completely gone and the pseudo-plug 


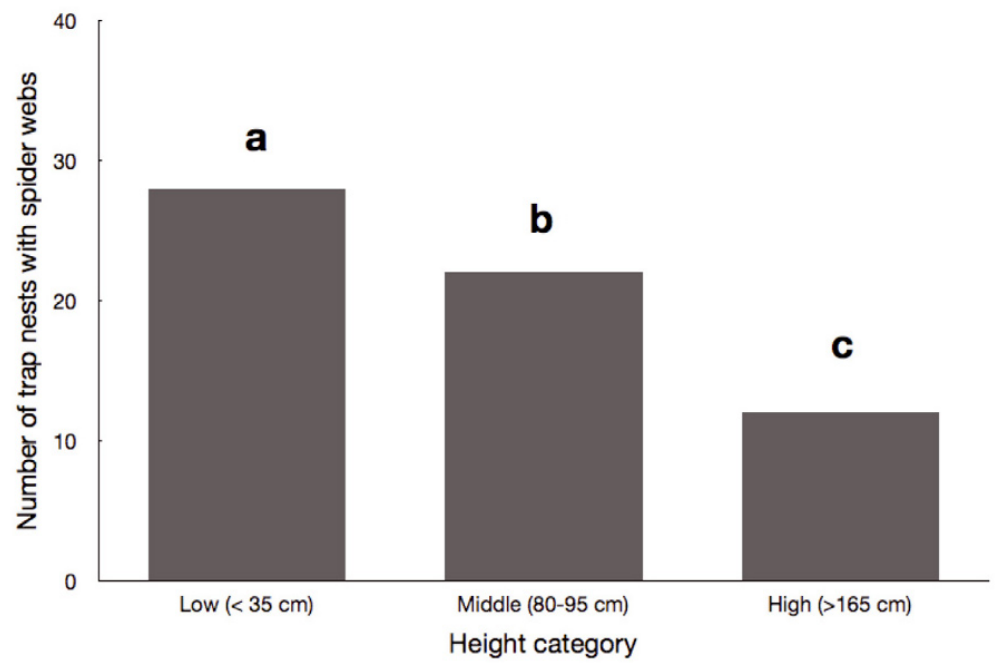

Figure 8. Number of trap nests with spiderwebs constructed either on or in the trap entrance, arranged by height category. High traps were significantly less likely than middle traps $\left(\chi_{\mathrm{df} 1}^{2}=6.159, P=0.013\right)$, and middle traps significantly less likely than low traps $\left(\chi_{\mathrm{df} 1}^{2}=4.206, P=0.0403\right)$, to contain spiderwebs. Two of these trap nests (one at the middle level and another at the high level) contained pubescence prior to the construction of the spiderwebs.

doubled in size. We removed the ants from the trap nest and placed them in $100 \%$ ethanol at $-20{ }^{\circ} \mathrm{C}$.

Also on 15 July, we discovered a number of individuals of a smaller ant species (Crematogaster lineolata) inside four more high level, wool containing trap nests. We removed these ants from the nests and stored a small number of individuals using the same protocol as above. All four of these trap nests still contained wool at the end of the field season.

Anti-ant measures taken on 16 July (see methods) seemed to prevent further attacks. We included all five ant-parasitized nests in our analysis of nest initiation preferences; we did not, however, include the pseudo-plugged nest in our analysis of "completed" nests.

\subsection{Female aggression at nest entrances}

On 17 July, we observed a female attempt to enter a nest as another female was exiting. The exiting female chased the first away from the nest entrance and into the center of the enclosure, where the two bees circled each other in a manner reminiscent of the aggressive spiral flights of males (Severinghaus, 1981). This was the only time we observed such behavior either within the enclosures or under natural conditions.

\section{DISCUSSION}

Relative size is an important determinant of male behavior in A. manicatum, a species in which large males consistently outcompete smaller males in the fight for territories and their associated fitness benefits (Müller, 1987; Starks and Reeve, 1999). Size differences between populations are intriguing, then, as they may shed light on the factors determining body size. Male bees taken from the Brooklyn population of $A$. manicatum were significantly larger than their male counterparts captured near Boston; this effect was so marked that the mean head size of Boston males converged upon that of Brooklyn females, erasing any sexual dimorphism between these groups. The reason for this difference may lie in the field sites themselves.

Brooklyn Botanic Garden comprises 52 acres of cultivated plantings that include 
several species visited by $A$. manicatum; by contrast, the Longfellow National Historic Site contains a single formal flower garden, approximately $20 \mathrm{~m} \times 30 \mathrm{~m}$, and a more limited number of plant species used by the bees. The floral territories from which we captured bees on the Tufts University campus were even smaller, were spaced at a considerable distance from one another, and contained only a single species used by A. manicatum. Indeed, Müller (1987) found similar size differences between a group of bees captured in a European botanical garden and another captured from smaller gardens in Ithaca, New York. Taken together, these results may support previous assertions (Sugiura, 1994) that nutrition plays a key role in the determination of body size in megachilid bee species, though we cannot yet rule out genetic differences between populations.

Earlier reports of trap nesting in wild populations of $A$. manicatum suggested that females might preferentially build their nests in locations high above the ground; in fact, all four such nests reported by Kurtak (1973) and by Severinghaus et al. (1981) were collected from the upper stories of man-made structures. Our results support this hypothesis, and show that under semi-natural conditions females overwhelmingly choose the highest available cavities in which to build their nests. This behavior may serve an adaptive purpose by limiting the exposure of nest sites to interference by predators or parasites; indeed, the presence of spiderwebs on or within the trap nests in our enclosures was significantly skewed toward lower elevation traps. While we did find ants in high level traps within our enclosure, this may not reflect what happens in nature, where nests may be considerably higher than the options available to captive bees.

To our knowledge, ours is the first report of possible ant predation on nests of A. manicatum. Nevertheless, there have been reports of nest parasitism by unidentified arthropods (Kurtak, 1973) and by cleptoparasitic Anthidiini (reviewed in Müller, 1987), and Sugiura (1994) reported high levels of infestation (21.8\% of all nests) of A. septemspinosum nests by a meloid beetle, Zonitis japonica. Whether ants feed on A. manicatum larvae, the pollen mass, or on the unidentified secretions that bind the nest material together, remains an open question.

Females may also prefer to build nests high above the ground and far from floral territories (Severinghaus et al., 1981) as a means of escaping nest usurpation by other $A$. manicatum females. Vinson and Frankie (2000) reported on conspecific nest usurpation in the trap nesting bee Centris bicornuta and suggested that the oily entrance plugs with which these females close their nests may be an adaptation against such usurpation (2000). It is at least plausible that the heavy fortifications of the Anthidium terminal plug serve a similar purpose. While our study did not rigorously track individual female nest visitations, the seemingly aggressive interaction between two females at a nest entrance warrants further investigation.

A. manicatum holds great promise as a model organism in studies of sexual selection, alternative phenotypes, recognition systems, and aculeate nesting behavior. Unfortunately, this promise remains largely unfulfilled due to the limitations of field based research protocols. Indeed, studies of nesting behavior face particular difficulties, as natural nests have proven difficult to locate, and attempts to keep A. manicatum in captivity have been relatively unfruitful (Kurtak, 1973). Here we describe methods for the successful maintenance of both male and female A. manicatum in a field enclosure under semi-natural conditions. Our results echo Sugiura's (1994) success using similar methods to study the congeneric $A$. semtemspinosum in Japan. His study of the effects of parental investment on offspring sex ratio, as well as ours of nest site selection preferences, demonstrate the power of these methods to resolve previously unanswerable questions about the biology of anthidiine bees.

\section{ACKNOWLEDGEMENTS}

We owe our thanks to several individuals without whose assistance this work could not have been completed: Dr. Gerry Moore at Brooklyn Botanic Garden and Mona McKindley and Jim Shea at the National Park Service were exceedingly patient with periodic visits from the bee collectors. At 
Tufts, Dr. Frances Chew and Dr. Sara Lewis loaned equipment and provided feedback, Tegan Morton assisted with collections at the Brooklyn field site, and Susan Weiner and Dr. George Ellmore helped with the identification of ants and plants, respectively. Noah Wilson-Rich provided assistance with data analysis. L. Mairin Odle and Burton Payne, as well as Dr. Klaus Hartfelder and two anonymous referees, reviewed previous drafts of this paper and contributed valuable suggestions for improvement. In addition, this research was supported by a National Science Foundation REU site award to Tufts University (DBI-0649190).

\section{Legal compliance}

All experimental procedures comply with current United States law.

\section{Choix du site du nid chez l'abeille cotonnière An- thidium manicatum, et méthodes pour l'utilisa- tion de cette espèce comme modèle d'étude.}

Megachilidae / espèce introduite / abeille solitaire / méthodes d'observation / milieu fermé

Zusammenfassung - Nistplatzwahl der europäischen Wollbiene Anthidium manicatum, mit einer Methodenbeschreibung zur Untersuchung einer neuen Modellspezies. Die europäische Wollbiene Anthidium manicatum hat große Chancen, als Modellorganismus für Untersuchungen über sexuelle Selektion, alternative Phänotypen, Erkennungssysteme und Nistverhalten aculeater Bienen etabliert $\mathrm{zu}$ werden. Bis es dazu kommt, müssen jedoch einige Beschränkungen ausgeräumt werden, die Freilandarbeiten kompliziert gestalten. Die betrifft insbesondere das Nistverhalten, da natürliche Nester nicht leicht zu finden sind und, falls dies doch gelingt, es reichlich schwierig ist, A. manicatum künstlich zu halten. Wir beschreiben hier die Ergebnisse einer Untersuchung zur Nistplatzwahl, die 2009 mit einer künstlich gehaltenen Population in Boston, Massachusetts, und in Brooklyn, New York, gefangener A. manicatum Männchen und Weibchen durchgeführt wurde. Von Interesse ist hierbei zunächst, dass wir GröBenunterschiede zwischen den Populationen aus Boston und Brooklyn fanden, wobei Männchen, die in Boston gesammelt worden waren, kleinere Kopfbreiten aufwiesen als solche aus Brooklyn (Abb. 4). Diese Größenunterschiede könnten auf Unterschiede in den Nahrungsressourcen an den beiden Standorten zurückzuführen sein. Zum zweiten beschreiben wir hier ein Verfahren zur
Haltung dieser Bienen in Flugkäfigen unter halbnatürlichen Bedingungen. In den Flugkäfigen wurden Futterquellen, Nistmaterialien und Bambusnistfallen in unterschiedlicher Höhe ausgebracht. Die Ergebnisse zeigten, dass die Weibchen hoch über dem Boden angebrachte Nistplätze bevorzugten (Abb. 6 und 7). Da diese höher gelegenen Nistplätze auch deutlich weniger Spinnweben aufwiesen, als solche, die näher am Boden lagen, deutet dies auf eine adaptive Erklärung für die Nistplatzwahl hin (Abb. 8). Trotz der hohen Mortalität, die kurz nach dem Einführen der Bienen in die Flugkäfige zunächst eintrat, hat unserer Meinung nach die hier beschriebene Haltungsmethode ein großes Potential für Studien zur Biologie von A. manicatum.

\section{Megachilidae / eingeführte Art / solitäre Biene / Haltungsmethode}

\section{REFERENCES}

Cytel (2003) StatXact 6 ${ }^{\circledR}$. Cytel Software Corporation, Cambridge, MA.

Darwin C. (1871) The descent of man, and selection in relation to sex, in: Wilson E.O. (Ed.) From so simple a beginning: the four great books of Charles Darwin, W. W. Norton \& Co., New York, pp. 978-979.

Gibbs J., Sheffield C.S. (2009) Rapid range expansion of the wool-carder bee, Anthidium manicatum (Linnaeus) (Hymenoptera: Megachilidae), in North America, J. Kans. Entomol. Soc. 82, 21-29.

Kirby W., Spence W. (1857) An introduction to entomology, or elements of the natural history of insects, 7th ed. Longman, Brown, Green, Longmans, \& Roberts, London.

Kurtak B.H. (1973) Aspects of the biology of the European bee Anthidium manicatum (Hymenoptera: Megachilidae) in New York State, MS thesis, Cornell University.

Melander A.L. (1902) The nesting habits of Anthidium, Biol. Bull. 3, 27-32.

Michener C.D. (2000) The bees of the world, The Johns Hopkins University Press, Baltimore, pp. 474-520.

Müller U.G. (1987) Dimorphic males in the European wool-carder bee Anthidium manicatum (Megachilidae: Hymenoptera), MS thesis, Cornell University.

Pechuman L.L. (1967) Observations on the behavior of the bee Anthidium manicatum (L.), J. N.Y. Entomol. Soc. 75, 68-73.

Severinghaus L.L., Kurtak B.H., Eickwort G.C. (1981) The reproductive behavior of Anthidium manicatum (Hymenoptera: Megachilidae) and the significance of size for territorial males, Behav. Ecol. Sociobiol. 9, 51-58. 
Shreeves G., Field J. (2008) Parental care and sexual size dimorphism in wasps and bees, Behav. Ecol. Sociobiol. 62, 843-852.

Smith F. (1855) Catalogue of British Hymenoptera in the collection of the British Museum, part I: Apidae - bees, Taylor \& Francis, London, pp. 184-187.

SPSS (2008) SPSS GradPack ${ }^{\circledR}$ version 17.0 for Windows. SPSS, Inc., Chicago (IL).

Starks P.T., Reeve H.K. (1999) Condition-based alternative reproductive tactics in the wool-carder bee, Anthidium manicatum, Ethol. Ecol. Evol. 11, 71-75.

Sugiura N. (1994) Parental investment and offspring sex ratio in a solitary bee, Anthidium semptemspinosum Lepeletier (Hymenoptera: Megachilidae), J. Ethol. 12, 131-139.

Vinson S.B., Frankie G.W. (2000) Nest selection, usurpation, and a function for the nest entrance plug of Centris bicornuta (Hymenoptera: Apidae), Ann. Entomol. Soc. Am. 93, 254-260.

Ward J.D. (1928) An unrecorded habit of the male of the bee Anthidium manicatum, L., Entomologist 61, 267-272.

Westrich P. (1989) Die Wildbienen BadenWürttembergs, Eugen Ulmer Verlag, Stuttgart.

Wirtz P., Szabados H., Pethig H., Plant J. (1988) An extreme case of interspecific territoriality: male Anthidium manicatum (Hymenoptera: Megachilidae) wound and kill intruders, Ethology 78, 159-167. 